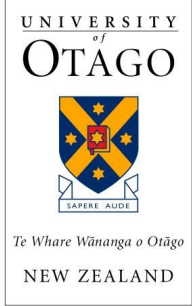

ISSN 0111-1760 (Print)

ISSN 1178-2293 (Online)

University of Otago

Economics Discussion Papers

No. 0811

School of Business

Unlimited Future, Unlimited Possibilities

Te Kura Pakihi

December 2008

\title{
Which Institutions are Good for Your Health? The Deep Determinants of Comparative Cross-country Health Status*
}

\author{
Stephen Knowles and P. Dorian Owen \\ Department of Economics, University of Otago, PO Box 56, Dunedin 9054, New Zealand
}

\begin{abstract}
We extend the literature on the deep determinants of economic development by focusing on life expectancy, instead of income per capita, as an indicator of economic development, and by examining the role of informal, as well as formal, institutions. Our empirical results suggest that formal and informal institutions are substitutes. Improving informal institutions has positive effects on life expectancy that are statistically significant for most countries and stronger than the effects of improving formal institutions. The gains from improving informal institutions are greatest for countries in which institutions are weakest. Geographical factors also help explain cross-country variation in life expectancy.
\end{abstract}

Keywords: Life expectancy, health, deep determinants, institutions, social capital, geography

JEL Codes: O10, I10

Contact details:

Stephen Knowles Tel: 6434798350 Email: sknowles@business.otago.ac.nz

Dorian Owen

Tel: 6434798655 Email: dowen@,business.otago.ac.nz

\footnotetext{
* We are grateful to participants at the Otago International Health Research Network Conference, Dunedin (November 2008) for helpful feedback on an earlier version of this paper.
} 


\section{Introduction}

People in most developing countries suffer from poorer health and live shorter lives, on average, than people in rich countries. In 2005, average life expectancy at birth in Japan was 82 years compared to 35 years in Botswana and Lesotho. The aim of this paper is to follow the tradition of the literature on the deep determinants of economic development and examine how much of the cross-country variation in life expectancy can be explained by institutional and geographical variables.

In the deep determinants literature, factors such as physical and human capital per worker and technology, which appear in the aggregate production function, are themselves considered to be joint outcomes. They are 'proximate determinants' of development, variations in which require explanation. Deep determinants, by contrast, are variables that explain differences in the proximate determinants; they are the underlying, fundamental, or 'deep' determinants that shape these proximate outcomes, which, in turn, are reflected in variation in economic wellbeing across countries. For example, high-quality institutions such as laws protecting private property from expropriation (a deep determinant) are likely to lead to high levels of physical capital accumulation (a proximate determinant) and, hence, higher levels of income per capita. Deep determinants are considered to be relatively slow-moving, durable characteristics of a society, such as its geography and the quality of its institutions, the influence of which have a pervasive effect on all aspects of development over long periods of time.

Income per capita is the standard proxy for economic development in this literature. In addition, the focus is almost exclusively on the role of formal, rather than informal, institutions in explaining cross-country differences in the level of development. Following North (1990), formal institutions can be thought of as written rules and regulations, for example, property and contract law, whereas informal institutions include norms, conventions and the level of trust and cooperation within society. This paper extends the existing literature in two main ways. 
Firstly, we focus on life expectancy as an alternative indicator of economic development. Secondly, we examine the role of informal, as well as formal, institutions as a potential deep determinant of development.

Concepts relevant to the analysis of the role of informal institutions also feature in discussions of social capital and cultural economics (Knowles, 2007). Social capital is a notoriously difficult term to define, but, at the risk of generalising to some extent, most definitions include the notions of trust, a shared set of cooperative norms, and networks between individuals (Putnam et al., 1993; Knack and Keefer, 1997). Trust and norms of generalised morality also feature in work on the economics of culture (Platteau, 1994a, b; Inglehart and Baker, 2000; Guiso et al., 2006; Tabellini, 2007). Given the similarities between social capital and informal institutions, it should come as no surprise that our empirical proxies for informal institutions reflect their common heritage.

The remainder of the paper is organised as follows. Section II briefly reviews existing work on the deep determinants of development, along with some relevant studies on the effects of social capital on health outcomes across countries. Section III analyses why institutions (both formal and informal) and geography may be expected to affect health outcomes. Our empirical results are presented in Section IV, with Section V concluding.

\section{Deep Determinants of Economic Development}

Beginning with Hall and Jones (1999), several papers have analysed the relative importance of institutions and geographical factors in explaining cross-country differences in income per capita (for example, Acemoglu et al., 2001; Acemoglu et al. 2002; Easterly and Levine, 2003; Sachs, 2003; Rodrik et al., 2004; Olsson and Hibbs, 2005).

The quality of institutions is typically measured using survey data on variables such as the degree of protection against expropriation or the extent to which contracts are enforceable. 
Measures of geography include distance from the equator, whether or not a country is landlocked and the proportion of the population that is at risk of contracting malaria. Early influential studies (Hall and Jones, 1999; Acemoglu et al., 2001; Easterly and Levine, 2003; Rodrik et al., 2004) emphasise the importance of institutions, arguing that, after controlling for institutional quality, geography has little direct effect on income. However, more recent contributions (for example, Sachs 2003; Olsson and Hibbs 2005; Carstensen and Gundlach, 2006) find evidence of a stronger role for geographical variables.

A key issue in the deep determinants literature is the need to deal with potential endogeneity of the explanatory variables. Although geographical variables such as distance from the equator and mean temperature are exogenous, the risk of malaria, for example, is potentially endogenous as there are steps richer countries can take to reduce malaria risk. Institutions are also potentially endogenous as richer countries are likely to demand, and are more able to afford, better quality institutions. For this reason, estimates are typically obtained using instrumental variables (IV) methods.

The deep determinants literature focuses on formal, rather than informal, institutions. Most deep determinants studies cite North's (1990: 3) seminal definition of institutions as 'the rules of the game in a society or, more formally, ... the humanly devised constraints that shape human interaction'. However, North emphasised that not only formal institutions (such as laws and regulations enacted by governments) but also informal institutions (such as conventions, norms and codes of behaviour) are important determinants of economic performance. Informal institutions expected to have a positive effect on economic development include norms of trust and reciprocity, which underpin market transactions. As we argue below, informal institutions are also likely to be determinants of health indicators such as life expectancy.

A few existing studies do consider a role for informal institutions or social capital in explaining cross-country differences in income or health status. Tabellini (2007) analyses the 
effect of culture on per capita output across regions in European countries, but his paper also includes some cross-country regressions examining relationships between different indicators of culture and governance, that is formal institutions. Tabellini's measure of culture includes survey-based information on the extent of trust, whether people believe children should be taught to respect others, whether they should be taught to be obedient (which Tabellini argues will have a negative effect on economic performance), and whether people believe they have control over their own destiny. Some of these variables could also be considered as measures of social capital or informal institutions, and are used in our empirical work. Tabellini's paper makes a strong case for the relevance of values and behavioural norms in explaining different experiences of economic development, but it does not adopt a deep determinants perspective, as neither formal institutions nor geographical characteristics are included as regressors explaining regional per capita income.

Voigt and Park (2008) examine the effects of separate proxies for formal institutions and social capital on total factor productivity (TFP) in a cross-country empirical analysis. They examine the direct effects of values and norms on TFP and their indirect effects via formal institutions and an indicator of social capital. In turn, social capital is assumed to affect formal institutions but not to directly affect TFP. Their modelling framework, an extension of that of Hall and Jones (1999), therefore imposes untested exclusion restrictions on the effect of social capital on TFP and also of formal institutions on social capital.

The approach adopted by Ahlerup et al. (2008) is the most closely related to ours, in that the explanatory variables in their model include a measure of formal institutions (covering bureaucratic quality, law and order, and corruption), social capital (measured as generalised trust) and their multiplicative interaction. However, the focus of their cross-country empirical analysis is on explaining the growth of GDP per capita (from 1995-2005) or the rate of investment, not health status. Also, rather than using a deep determinants approach, they fit a 
Barro-type growth regression that includes base-period income, investment prices and human capital (proxied by life expectancy). ${ }^{1}$ Their results imply that formal institutions and trust are substitutes in terms of enhancing growth; consequently, social capital has a stronger positive effect on growth for countries with lower quality formal institutions.

In assessing the role of formal institutions on economic development, most deep determinants studies proxy the latter by income per capita. However, a small number of studies, acknowledging that income per capita may be an imperfect proxy, examine the determinants of alternative measures of economic development. Batten and Martina (2007) analyse the effect of formal institutions and geography, as well as the degree of trade openness, on the Human Development Index and find the proportion of the population at risk of contracting malaria to be the most important deep determinant. Jones et al. (2007) analyse the effect of formal institutions and some aspects of geography on life expectancy and school enrolment rates. They find formal institutions to be a key predictor of life expectancy, but do not consider informal institutions. Mean temperature and the extent to which a country is landlocked do not have statistically significant effects. They do not include malaria risk as an explanatory variable in their life expectancy equation, arguing that malaria is a proximate, rather than deep determinant of life expectancy. Galor and Moav (2007) find that the number of years since the ancestors of a country's population experienced the Neolithic Revolution is significantly positively correlated with contemporary life expectancy. Among their control variables are distance from the equator and a measure of formal institutions, both of which have statistically significant effects in some specifications. $^{2}$

There is also a more extensive literature, reviewed in Islam et al (2006), that examines the effect of social capital across countries on health indicators, including life expectancy. These studies normally do not control for formal institutions and geography; instead, proximate determinants, such as immunisation rates, the number of doctors and income per capita, are 
often included as control variables. From a deep determinants perspective, this raises the question of what determines these proximate factors. Relevant studies include Lynch et al. (2001) and Kennelly et al. (2003). Both analyse the effects of social capital and inequality on life expectancy for a cross-section of high-income countries. In both studies, social capital, proxied by different World Values Survey (WVS) responses, is not statistically significant in explaining cross-country differences in life expectancy, although Lynch et al. (2001) find some evidence of a significant correlation between some forms of social capital and specific causes of mortality, such as coronary heart disease. The lack of statistical significance of social capital may be the result of including other proximate determinants and income, which could be controlling for some of the effects of social capital. Also, the possibility of bias due to endogeneity of several of the explanatory variables is not considered.

Compared to the studies discussed above, our approach adopts a health-status measure, life expectancy, as an alternative proxy measure for economic development, and examines the effects of formal and informal institutions, and their interaction, in a deep determinants framework.

\section{The Effects of Geography and Institutions on Health}

\section{Geography and Health}

The causal effects of geographical location on health status involve several direct and indirect mechanisms. The direct effects are the most obvious: many diseases are more prevalent in tropical areas (Bloom and Sachs, 1998; Gallup et al., 1999; Sachs 2001, 2003). The spatial distribution of human pathogens displays what biologists term a 'latitudinal species diversity gradient'; that is, the number of parasitic and infectious disease species is inversely related to latitude, and climatic rather than socio-economic factors are primarily responsible for this pattern (Guernier et al., 2004). Landes (1998: 7) notes that '[h]eat, especially year round heat, 
... encourages the proliferation of life forms hostile to man'. Sachs $(2001,2003)$ emphasises the particularly pernicious effects of malaria on health and productivity. This is essentially a tropical disease as an ambient temperature of at least $18^{\circ} \mathrm{C}$ is required for anopholene mosquitoes, the crucial vectors in malaria transmission, to be infective (Sachs, 2001). By contrast, winter frosts, lacking in tropical areas except at high altitudes, act as an important control on the spread of many parasites, pathogens and pests (Masters and McMillan, 2001). The maximum range of precipitation is strongly correlated with pathogen diversity (Guernier et al., 2004) and large within-year variation in precipitation is another feature of tropical areas. In our empirical work, we use the proportion of a country's area that lies in the tropics as an explanatory variable, but also examine absolute latitude as an alternative summary measure of tropical geographical location, as this variable has been used in several deep determinants studies of income per capita.

Climate and other aspects of geography also have indirect effects on health. The extreme heat and humidity in tropical countries contributes to low soil fertility and low agricultural productivity (Bloom and Sachs, 1998; Sachs 2001). This can have adverse effects on the adequacy of nutritional standards and consequent implications for susceptibility to disease for children and adults.

Geographical factors that affect income per capita are also likely to have an effect on health. Cross-country studies focusing on long-run effects usually find a positive association between income and health, although there is a lack of consensus on whether the effect is predominantly from income to health (Pritchett and Summers, 1996) or bi-directional (Knowles and Owen, 1995, 1997; Bloom and Canning, 2000; Commission on Macroeconomics and Health, 2001). ${ }^{3}$ On either interpretation, higher levels of income per capita improve health status. ${ }^{4}$ For example, the extent to which a country has access to the sea is included as a geographical determinant of income in some empirical studies, primarily on the grounds that lack of access to the coast can 
hamper openness to trade (Gallup et al., 1999). This can also cause countries to be dependent on good political relations with their neighbours and reliant on the latter's infrastructure, administrative policies and political stability (Faye et al., 2004). If access to a coastline has implications for income per capita, then, to the extent that income affects health, there will be indirect effects on health status. More specifically, better access to trade can facilitate diffusion of medical knowledge and importing of new technologies, medicines and medical resources that improve health outcomes (Owen and Wu, 2007; Papageorgiou et al., 2007). There may also be even more direct effects on health if access to the coast affects diet or disease ecology and methods of controlling vectors (McArthur and Sachs, 2001).

\section{Institutions and Health}

Empirical studies in the deep determinants literature emphasise the significance of the effect of formal institutions on income per capita. To the extent that additional income provides resources to improve health status, as discussed above, then better quality formal institutions will have indirect effects, via income, in improving health status.

More directly, the quality of institutions is important for the provision of public goods, such as a health system. Effective state provision of a tax-funded public health system and supporting public health infrastructure (such as water and sanitation) is usually associated with a sufficiently strong tax base, adequate organizational capacity and a well-developed institutional environment, reflected in secure property rights, effective government and control over corruption (Fafchamps, 2006). In poorer countries, in addition to a lack of resources, corruption (manifested in state-provided drugs not reaching patients), absenteeism among health workers (especially in rural areas), a lack of adequate monitoring and regulation of private sector providers, and general bureaucratic inefficiency adversely affect the quality of delivery of health services (Chaudhury et al., 2006; Cutler et al., 2006). Poor-quality institutions may contribute to the finding of no statistically and numerically significant relationship 
between health spending and health outcomes in some empirical studies (Filmer and Pritchett, 1999). In extreme situations, where the inadequacy of institutions leads to internal or crossborder conflict and political instability, violence may lead directly to deaths, injuries and destruction of health facilities.

If formal institutions are inadequately developed, informal institutions can act as a substitute (Fafchamps, 2006). For example, religious and political groups, relying on interpersonal trust and in-group leadership, can build clinics and hospitals with a view to providing comprehensive primary health care for local communities. Whereas informal institutions are generally considered to be a second-best solution compared to the rule of law and effective governance, rapid introduction of the latter into poor countries is difficult and can have adverse consequences (Dixit, 2004). In developing countries, social relations between people are often crucial for effective delivery of health care (Woolcock and Radin, 2008).

In principle, social capital can, in different circumstances, either be a substitute or a complement for formal institutions in the provision of public goods (Fafchamps, 2006). Indeed, formal and informal institutions could well be substitutes at a macro level (in cross-country regressions) and complements at the micro level, if, for example, communities supplement a state-funded health system, based on good-quality formal institutions, with local initiatives and voluntary involvement that improves the quality of local health care and service provision.

\section{Empirical Results}

To assess the statistical and quantitative significance of the effects of both formal and informal institutions, and geographical factors, in a deep determinants framework, we obtain parameter estimates for the following model

$$
\begin{gathered}
-\ln (85-L E)_{i}=\alpha+\beta_{1} \text { Formal }_{i}+\beta_{2} \text { Informal }_{i}+\beta_{3} \text { Formal }_{i} \times \text { Informal }_{i}+\beta_{4} \text { TropicArea }_{i} \\
+\beta_{5} \text { Land100km }_{i}+\beta_{6} \text { Africa }_{i}+\beta_{7} \text { Communist }_{i}+\varepsilon_{i}
\end{gathered}
$$


in which $L E$ is life expectancy at birth in 2005, Formal a measure of formal institutions, Informal a measure of informal institutions, TropicArea the proportion of land area within the tropics, Land100km the proportion of land area within $100 \mathrm{~km}$ of the coast, Africa a dummy variable equal to one if a country is in Africa, Communist a dummy variable for countries with a communist legacy and $\varepsilon$ a country-specific error term. Subscript $i$ denotes country $i$.

The dependent variable is a logarithmic transformation of the shortfall of average life expectancy at birth from 85 years. This transformation allows for a biological upper bound for average life expectancy in the sample (Knowles and Owen, 1995, 1997) and reduces heteroskedasticity in the errors.

Formal is the arithmetic mean of the values in 2005 of six different measures of formal institutions from the Worldwide Governance Indicators (WGI) (Kaufmann et al., 2007). ${ }^{5}$ These indices are measured in units following a $N(0,1)$ distribution with virtually all scores in the range -2.5 to 2.5. The components of Informal (discussed below) are measured on a 0 to 100 scale. To make comparisons between the coefficients on Formal and Informal easier, we convert Formal to a 0 to 100 scale.

Informal is the arithmetic mean of three indices: the extent of generalised trust (Trust), the degree of control individuals believe they have over their lives (Control) and whether individuals believe parents should teach their children tolerance and respect for others (Respect). We also consider results for a variant of Informal calculated as the arithmetic mean of Trust and Control. Data for the three indices are from the fourth wave of the World Values Survey (WVS) (Inglehart et al., 2004). Trust, Control and Respect are all included in Tabellini's (2007) index of culture, discussed in Section II, while Trust and Control are equivalent to two of the six alternative proxies for the 'psychosocial environment' adopted by Lynch et al. (2001). 
The parameters $\beta_{1}$ and $\beta_{2}$ are hypothesised to be positive. Including an interaction term, the product of Formal and Informal, allows us to test whether there is complementarity $\left(\beta_{3}>0\right)$ or substitutability $\left(\beta_{3}<0\right)$ between formal and informal institutions.

TropicArea and Land100km are geographical deep determinants that have been used in studies of income levels (for example, Gallup et al., 1999; Sachs 2003) and for which data availability does not impose additional constraints on sample size. Because African countries overwhelmingly dominate the bottom end of the distribution of average life expectancy across countries, an African dummy variable is included. A dummy variable for a communist legacy (equivalent to the socialist legal origin dummy of La Porta et al. (1999)) is included to pick up the long-term effects on health status of aspects of the social and economic structure of previously communist countries that may not be adequately reflected in the institutions measures.

Several studies in the deep determinants literature include the proportion of the population at risk of malaria as a geographical deep determinant of income per capita (for example, Sachs, 2003; Carstensen and Gundlach, 2006). In the current context, the risk of catching a potentially fatal illness is more appropriately considered as a joint outcome with life expectancy. Hence, we do not include malaria risk as a potential deep determinant in our benchmark specification in equation (1) but investigate the implications of including it in our later robustness analysis.

[Table 1 about here]

Summary statistics for the key variables of interest are presented in Table 1, for the sample of 73 countries for which we have data on the indices of informal institutions. A list of countries in the sample is given in Appendix 1 and data sources in Appendix 2. The sample is made up of approximately equal numbers of developed and developing countries with a relatively greater representation of Eastern European transition economies than is common in 
existing deep determinants studies, reflecting the improved coverage of these countries in the WVS and WGI data. There is significant variation in all the variables. The maximum value for Formal is 88.98 (Iceland), with the minimum value being 16.56 (Zimbabwe). The maximum value of Informal, including all three components, is 77.67 (Sweden), with a minimum of 31.67 (Pakistan). The simple correlation between Formal and Informal is 0.61 and, as the cross-plot in Figure 1 shows, the proxy measures for the two categories of institutions are far from perfectly correlated, suggesting there may be additional informational content in the informal institutions variable.

[Figure 1 about here]

TropicArea, Land100km, Africa and Communist are treated as exogenous, but Formal and Informal are both potentially endogenous. More highly developed countries, in which people live longer, are more able to invest in higher quality formal institutions. If formal and informal institutions are substitutes, and the former are less well developed, the returns to the latter are higher, so that more effort is likely to be made to create social capital (Fafchamps, 2006). Also, in countries where average health status is more favourable, people may be more inclined to believe that they have control over their lives. A population with a higher average life expectancy and a higher average age may be more trusting, if trust in others increases with age, as the results in Alesina and La Ferrara (2002) suggest. With endogenous explanatory variables, Ordinary Least Squares (OLS) estimates of equation (1) would be potentially biased and not reflect the causal effect of institutions on health. To address such concerns, and to reduce attenuation bias due to measurement error, we use IV estimation methods, drawing on a variety of instruments used in the literature on the deep determinants of income levels.

StateHist is an index of 'state antiquity' constructed by Bockstette et al. (2002). Values of StateHist lie between zero and one, with higher values indicating longer spans of state antiquity. Countries with a long state history are likely to have had the time to develop higher quality 
formal institutions. StateHist is correlated with a number of measures of formal institutions (Bockstette et al., 2002), suggesting it should be a good instrument for our purposes.

Hall and Jones (1999) argue that EngFrac, the proportion of the population speaking English, and EurFrac, the proportion of the population speaking one of five major Western European languages (including English), proxy for the degree of Western European influence and hence the quality of formal institutions, which were typically imported from Western Europe. Although their argument is somewhat Eurocentric, their data show a significant positive correlation between formal institutions and both EngFrac and EurFrac. We include EngFrac in our instrument set, but not EurFrac which adds relatively little additional explanatory power in the implied first-stage regressions.

The dummy variable, EngLegor, indicates whether a country has a common law system, reflecting an English legal origin. Legal origin is correlated with a wide range of legal and regulatory outcomes that have important consequences for economic and social outcomes (La Porta et al., 1999, 2008). In particular, common law countries with an English legal origin tend to have stronger protection of property rights and better enforcement of contracts than do countries with a more prescriptive civil law, particularly of French legal origin. La Porta et al. (2008: 286) characterise legal origin as 'a style of social control of economic life ... In strong form, ... we argue that common law stands for the strategy of social control that seeks to support private market outcomes, whereas civil law seeks to replace such outcomes with statedesired allocations.'

We also use the proportions of the population professing to be Protestant, Catholic and Muslim (labelled ProtFrac, CathFrac and MuslimFrac, respectively) as instruments. Weber (1958) emphasises the historical importance of the Protestant ethic in the spread of capitalism, arguing that Protestantism places an emphasis on honesty and taking personal responsibility for one's own fate. Inglehart and Baker (2000) define the Protestant ethic as involving relatively 
high interpersonal trust and a relatively high degree of social pluralism, and argue that these cultural traits have persisted over time, even as levels of religious observance have fallen. In contrast, hierarchical religions, such as Catholicism, are less likely to generate interpersonal trust than are more vertical religions, such as Protestantism (Putnam et al., 1993; Inglehart and Baker, 2000). Jones (1997: 766) argues that a person endowed with the Protestant ethic 'believes that positive outcomes are the result of his or her own attitudes and behaviour. A person with an external locus of control, by contrast, attributes outcomes to luck, fate, chance, or the influence of powerful others.'

Hence, overall, we would expect Trust, Respect and Control to be higher in historically Protestant countries. Consistent with this view, Trust is lower in countries with hierarchical religions, defined as Catholic, Eastern Orthodox or Muslim (La Porta et al., 1997; Berggren and Jordahl, 2006). Following La Porta et al (1997), Zak and Knack (2001) use the proportion of the population that is Catholic, Muslim, or Eastern Orthodox as an instrument for Trust. Tabellini (2007), in cross-country regressions, uses ProtFrac as an instrument for his culture index, which includes Trust, Control and Respect. Following these studies, we include ProtFrac, CathFrac and MuslimFrac in our instrument set.

Overall, StateHist, EngFrac and EngLegor are selected primarily due to prior arguments that they will act as good instruments for formal institutions, but they are also correlated with informal institutions (with significant $t$-values in first-stage regressions for Informal). Similarly, ProtFrac, CathFrac and MuslimFrac, included primarily as instruments for informal institutions, also add explanatory power as instruments for formal institutions (with significant $t$-values in first-stage regressions for Formal). ${ }^{6}$

As well as being relevant, that is, having high partial correlations with the endogenous explanatory variables, consistency of IV estimators requires the instruments to be exogenous, that is, uncorrelated with the error term (at least asymptotically). This requires that the 
instruments do not have direct effects on health status and are not correlated with omitted relevant variables. Not surprisingly, concerns about the validity of implied exclusion restrictions are common in cross-country applications of IV methods. As there are more instruments than endogenous variables, we report tests of overidentifying restrictions (Sargan, 1958; Hansen, 1982). These provide a test, although not necessarily powerful, of the null hypothesis that the instruments are uncorrelated with the errors in a correctly specified model.

A common problem with IV estimation of cross-country relationships in the growth and development literature is the relatively weak partial correlations between endogenous regressors and instruments. If instruments are weak, two-stage least squares (2SLS) estimates can exhibit severe finite-sample bias, especially when the degree of endogeneity is strong; also, their finitesample distribution can be very different from their asymptotic distribution, distorting the size of tests and the coverage of confidence intervals (Andrews and Stock, 2007).

For 2SLS estimation of the model in Table 2, column (i), the partial $R^{2}$ s between the endogenous regressors and the excluded instruments in the first-stage regression are 0.560 , 0.528 and 0.705 for Formal, Informal and Formal $\times$ Informal respectively, suggesting that the instrument set is reasonably strongly associated with each of the endogenous right-hand-side variables. However, Shea (1997) partial $R^{2} \mathrm{~s}$, which take into account intercorrelations between the instruments, are more modest $(0.307,0.221$ and 0.288 respectively), which suggests a potential weak instrument problem. This view is supported by the low values of the CraggDonald (1993) F-statistic compared to Stock and Yogo's (2005) critical values for this statistic as a test of weak instruments. ${ }^{7}$

[Table 2 about here]

Point estimates of the parameters are therefore obtained using Fuller's (1977) modified limited information maximum likelihood (LIML) estimator. Fuller's estimator, unlike standard LIML, has finite sample moments and, in terms of bias, is more robust than 2SLS when 
instruments are weak (Hahn et al., 2004; Stock and Yogo, 2005). In terms of its overall properties, Andrews and Stock (2007) recommend the use of Fuller's estimator with $\alpha=1$ or 4 for parameter estimation with weak instruments. ${ }^{8}$ For inference, Hansen et al. (2008) advocate the use of Fuller estimation with Bekker (1994) standard errors, especially when there are many instruments, or many weak instruments, but also in situations with a relatively low degree of overidentification. Stock and Yogo's (2005) results suggest that LIML has more accurate coverage rates (that is, closer to nominal values) than 2 SLS when instruments are weak. In the simulation studies by Hahn et al. (2004) and Flores-Lagunes (2007), the LIML or modified LIML estimators perform better overall than several other estimators, although any ranking is not definitive because both studies consider the case of only one endogenous regressor and the combination of LIML/Fuller estimation with Bekker standard errors is not examined.

The results obtained from 2SLS and Fuller estimation of equation (1) are presented in Table 2. ${ }^{9}$ In columns (i)-(iii), the informal institutions index includes three equally weighted components: Trust, Control and Respect. ${ }^{10}$ The estimated coefficients on Formal and Informal are both positive and statistically significant at the 1 per cent level. The coefficient on the interaction term $($ Formal $\times$ Informal $)$ is also statistically significant at the 1 per cent level, with a negative sign, suggesting that, on average, formal and informal institutions are substitutes with respect to explaining cross-country differences in life expectancy. ${ }^{11}$ This is similar to the finding of Ahlerup et al. (2008) in the context of explaining economic growth.

Institutions are not all that matters; geographical explanatory variables, TropicArea and Africa, also have statistically significant effects, as does Communist, although the coefficient on Land $100 \mathrm{~km}$ is not statistically significant. Without Land $100 \mathrm{~km}$, the results, in column (iii) are otherwise qualitatively unchanged. A similar pattern of results is evident in column (iv) in which Informal is defined as the equally weighted average of Trust and Control. 
The $p$-values for the Sargan tests imply that the overidentifying restrictions are not rejected, consistent with no direct effects of the instruments on life expectancy. For Fuller and LIML estimators, the concentration parameter, $\mu^{2}$, is a better criterion for evaluating accuracy of inference than first-stage $F$-statistics (Hansen et al., 2008). Hansen et al. (2008: 404) suggest that 'with few instruments the bias of LIML is very small once the concentration parameter exceeds 10 , and that the variance of LIML is quite small once the concentration parameter exceeds 20'. The models in Table 2 have $\mu^{2}$ values between 10 and 20 .

The marginal effects for Formal and Informal in equation (1) are given by:

$$
\begin{aligned}
& \partial[-\ln (85-L E)] / \partial \text { Formal }=\beta_{1}+\beta_{3} \text { Informal } \\
& \partial[-\ln (85-L E)] / \partial \text { Informal }=\beta_{2}+\beta_{3} \text { Formal }
\end{aligned}
$$

The statistically significant coefficient on, for example, Formal implies that formal institutions have a significant marginal effect on transformed life expectancy in countries where Informal is zero, which is not particularly informative if no country has a zero value for Informal. Also, statistical significance of the coefficients on Formal, Informal and the interaction term does not necessarily imply that the marginal effects of Formal and Informal are statistically significant at all (or even at any) relevant values of Informal or Formal respectively (Brambor et al., 2006). To investigate this further, we calculate the estimated marginal effects, and their 95 per cent confidence intervals, for the range of values of Formal and Informal in the sample. The 95 per cent confidence interval for the marginal effect of Formal is obtained as:

$$
\left(b_{1}+b_{3} \text { Informal }\right) \pm 1.96\left[\left(\operatorname{var}\left(b_{1}\right)+\operatorname{var}\left(b_{3}\right) \text { Informal }^{2}+2 \operatorname{cov}\left(b_{1}, b_{3}\right) \text { Informal }\right]^{1 / 2}\right.
$$

in which $b_{1}$ and $b_{3}$ are point estimates for $\beta_{1}$ and $\beta_{3}$ respectively, and $\operatorname{var}\left(b_{1}\right), \operatorname{var}\left(b_{3}\right)$ and $\operatorname{cov}\left(b_{1}, b_{3}\right)$ are the estimated Bekker variances and covariance of the relevant estimated parameters (Aiken and West, 1991). A similar expression applies for the marginal effect of 
Formal. The point estimates and confidence intervals for the marginal effects for the model in Table 2, column (iii) are represented graphically in Figures 2 and 3.

[Figures 2 and 3 about here]

The estimated marginal effect of Formal on transformed life expectancy is positive and statistically significant for countries with low ratings for Informal. As Informal increases, the marginal effect of Formal declines and ceases to be statistically significant for levels of Informal above about 43, approximately the rating for the quality of informal institutions in Latvia, the Russian Federation and Portugal. Improving the quality of formal institutions has a statistically significant positive effect on life expectancy for approximately only the lowest quintile of countries in the distribution of informal institutional quality in the sample. These include Pakistan, Armenia, Uganda, Turkey, Algeria, Azerbaijan, Georgia, The Philippines, Slovakia, India, Romania, Ukraine, Bangladesh and Brazil. Because the point estimate for the coefficient on Formal (0.074 in column (iii) of Table 2) is for the marginal effect when Informal takes the value of zero, the estimated size of the marginal effect is smaller for more relevant values of Informal. For example, for Pakistan (for which Informal $=31.67$ and $L E=$ 65), the estimated marginal effect for Formal is 0.032 ; an increase of 20 in Pakistan's quality rating for formal institutions, approximately a one standard deviation increase in Formal, other things equal, would therefore decrease the shortfall in life expectancy from 85 years by nearly 50 per cent, equivalent to an improvement in life expectancy of nearly 10 years. ${ }^{12}$ For Georgia $($ Informal $=40.7 ; L E=71)$ and Latvia $($ Informal $=43 ; L E=71)$, the estimated increases in life expectancy of a 20 unit increase in Formal are approximately 4.7 and 4 years respectively.

The estimated marginal effect of Informal on transformed life expectancy displays a similar declining pattern as Formal increases, but the marginal effect is larger and remains positive and statistically significant for a wider range of countries, up to values of Formal of approximately 66, about the rating for the quality of formal institutions in Slovakia and the Czech Republic. 
Approximately 63 per cent of countries in the sample are in this category, with the main exceptions being the OECD countries, Chile and, more marginally, Hungary, Taiwan, Slovenia and Estonia. For Zimbabwe (for which Formal $=16.56$ and $L E=42$ ), the estimated marginal effect for Informal is 0.09 , implying that an increase of 10 units in the quality rating for informal institutions, approximately a one standard deviation increase in Informal, other things equal, would decrease the shortfall in life expectancy from 85 years by approximately 60 per cent, equivalent to an improvement in life expectancy of nearly 26 years. For Azerbaijan $($ Formal $=32.4 ; L E=72)$, Peru $($ Formal $=40.9 ; L E=71)$, Romania $($ Formal $=50.3 ; L E=72)$ and Poland $($ Formal $=60.4 ; L E=75)$, the estimated effects of a 10 unit increase in Informal are increases in life expectancy of approximately 6.6, 6.3, 4.9 and 2.9 years respectively. Hence, in cases where the marginal effects on life expectancy of institutional improvements are statistically significant, the magnitude of these effects is also quantitatively significant but varies across countries.

Geographical variables also have quantitatively significant effects on the shortfall in life expectancy. A one standard deviation increase in TropicArea, other things equal, increases the shortfall from 85 years of life expectancy by approximately 23 per cent, equivalent to a decrease in life expectancy ranging from approximately 10 years, when $L E$ is 42 , to just over eight months, when $L E$ is 82 . The estimated average effect of a country being in Africa or a previously Communist state is to increase the shortfall in life expectancy by approximately 38 per cent and 26 per cent respectively.

[Table 3 about here]

We examine the robustness of our results to variation in the method of estimation and to inclusion of additional regressors. In Table 3, we report results for different estimation methods applied to the basic model in Table 2, column (iii). Fuller(4) corresponds to the Fuller modified LIML estimator with Fuller constant $\alpha=4$. As noted earlier, Fuller(4) has a smaller mean 
squared error than Fuller(1) and is recommended by Hahn et al. (2004) on the basis of their Monte Carlo simulations. The 2SLS and Fuller estimators are appropriate if the error terms are homoskedastic. If the errors are heteroskedastic, GMM estimation is more efficient but may have poorer small-sample properties, so 2SLS or LIML would be preferable if errors are homoskedastic. The results for the Pagan-Hall (1983) test for heteroskedasticity (based on levels and squares of the instruments) in Table 2 do not reject the null of homoskedasticity at conventional significance levels. However, as the test does not consider all possible forms for heteroskedasticity, we consider the sensitivity of the results to estimation methods that allow for less specific forms of heteroskedasticity. Column (iii) in Table 3 reports two-step GMM estimates, which are efficient for arbitrary heteroskedasticity, and heteroskedasticity-robust standard errors. For comparison, column (ii) reports two-step GMM based on the assumption of homoskedastic errors. Results for the continuously updated estimator (CUE) of Hansen et al. (1996), which generalises the LIML estimator to departures from homoskedasticity, are reported in column (iv). Compared to the Fuller(1) results in column (iii) in Table 2, the results in Table 3 display only relatively minor changers in estimated coefficients and marginal significance levels across the different estimation methods.

\section{[Table 4 about here]}

In Table 4 we check the robustness of the results to the inclusion of additional variables in the baseline model. Income inequality is arguably better thought of as an outcome, jointly determined along with average income levels, rather than a deep determinant of development. Nevertheless, there is an extensive literature on the effects of income inequality on health outcomes, reviewed in Deaton (2003). Therefore, in column (i), we examine the effects of adding the Gini coefficient for income inequality, Gini, to the model. ${ }^{13}$ The estimated effect of income inequality is negative and statistically significant, but the changes in the estimated effects of the institutions variables are relatively minor; the most noticeable difference is an 
increase in the absolute size of the coefficient on the Communist dummy. Thus, life expectancy is lower in countries where inequality is higher, even after controlling for the informal institutional environment. However, in column (i), Gini is included as an exogenous variable; if it is treated as an endogenous variable, then, with the same instrument set, Gini no longer has a statistically significant effect but all other coefficients are statistically significant, including that on Communist, and little changed compared to the benchmark model (results not reported).

Openness, or the degree of integration with world markets, is often considered as a potential deep determinant of income levels. Owen and Wu (2007) present panel-data evidence that more open economies also have higher average life expectancy (and lower infant mortality rates). In column (ii) we add Openness, Sachs and Warner's (1995) widely used index of the fraction of years a nation is 'open' during the $1965-1990$ period. As this is likely to be endogenous, we instrument it, augmenting our instrument set to include an updated version of Frankel and Romer's (1999) predicted trade shares instrument, FRTrade, derived by Frankel and Rose (2002). The effect of the openness measure is not statistically significant. The coefficient estimates for the institutions variables are little affected, but the coefficients on the Africa and Communist dummy variables are no longer statistically significant. Similar results are obtained using alternative measures of openness, such as updated versions of the Sachs and Warner openness measure (Wacziarg and Welch, 2008) or the Penn World Tables nominal openness measure, that is, (imports + exports) relative to GDP in national currencies, averaged over different time periods.

As noted in our discussion of equation (1), we do not include malaria risk, Malfal, as a deep determinant of health in our benchmark specification, regarding it instead as a proximate determinant. However, we check whether its inclusion affects the estimates of the other parameters (in column (iii)), adding to our instrument set the malaria ecology index, $M E$, used by Sachs (2003). Not surprisingly, the asymptotic $t$-values for the coefficients on TropicArea 
and Africa are reduced because of the prevalence of malaria in tropical areas, particularly in Africa. However, the coefficients on the institutions variables remain largely unaffected.

In column (iv) we include average latitude, AvLat, instead of TropicArea. Latitude has been widely used as a proxy for a country's geographical location in deep determinants studies (for example, Acemoglu et al., 2001; Rodrik et al., 2004; Fielding and Torres, 2008). Again, the coefficients on the institutions variables change relatively little.

In columns (v) and (vi) we examine the sensitivity of the results to using alternative measures of formal institutions. Rather than the aggregate WGI measure, we use two separate components: Rule of Law (Rule), in column (v), and Government Effectiveness (GovEffec), in column (vi). The corresponding interaction terms are also appropriately redefined. A similar pattern of results is obtained as in the benchmark specification; the main difference is the lack of statistical significance of the Communist dummy with Rule as the dependent variable. Overall, Tables 3 and 4 demonstrate the robustness of our key results to the choice of estimation method and additional control variables.

\section{Conclusions}

The existing literature on the deep determinants of economic development adopts an overly narrow perspective. It focuses almost exclusively on levels of income per capita as the key indicator of development. It also emphasises the role of formal institutions, especially those relating to the protection of property rights and the rule of law, neglecting consideration of informal institutions, such as conventions, norms and levels of trust and cooperation within society. In this paper, we therefore examine an alternative indicator of development, life expectancy at birth, and include measures for the quality of both formal and informal institutions among its potential deep determinants. 
Formal and informal institutions could, in principle, act as substitutes or complements, an issue we investigate by including a multiplicative interaction term in our empirical model. Our cross-country results suggest that they are substitutes at the aggregate level, a similar result to that found by Ahlerup et al. (2008) in explaining economic growth. The marginal effect on life expectancy of improving institutions is quantitatively most important when the quality of institutions is low. Improving the quality of formal institutions, however, has a positive statistically significant effect on life expectancy only for countries with relatively low-quality informal institutions, approximately those countries in the lowest quintile in the distribution of informal institutional quality in the sample. In contrast, improving informal institutions has a statistically and quantitatively significant positive effect on life expectancy for about 60 per cent of the countries in our sample. The main exceptions are the richer OECD economies, consistent with the finding of other studies (Lynch et al., 2001; Kennelly et al., 2003) that social capital does not have a significant impact on aggregate health status in wealthier nations.

Geographical variables also have quantitatively significant effects on life expectancy, in contrast to the, now somewhat eroded, early consensus in deep determinants studies that such factors have only indirect effects via the quality of institutions.

Although it is unwise to jump from cross-country aggregate empirical results to policy, it is not uncommon to hear claims that improvements in institutional quality hold the key to successful economic development. Our results suggest that, if results from the deep determinants literature are to be used to emphasise the importance of institutions, then the focus needs to be broadened to include informal institutions and the interaction between formal and informal institutions. For most countries, improvement in informal institutions appears to have more significant positive effects on health status compared to improving formal institutions, and the returns from improving informal institutions are most valuable for developing countries in which institutions are currently weakest. 


\section{Notes}

${ }^{1}$ Zak and Knack (2001) also estimate growth models that include both formal institutions and generalised trust as explanatory variables. Bjørnskov et al. (2008) do the same in modelling cross-country variation in self-reported life satisfaction. Unlike Ahlerup et al. (2008), neither of these studies allows for an interaction term between the two types of institutions, thus ruling out direct consideration of substitutability or complementarity.

${ }^{2}$ Other cross-country studies that find significant effects of measures of formal institutions on health status include Lazarova and Mosca (2007) and Klomp and de Haan (2008), but neither of these considers the possible effects of informal institutions or social capital, and they include income and other proximate determinants of health as explanatory variables.

${ }^{3}$ One example of a mechanism through which geography-induced variations in health can affect income per capita in the longer run is through investment in human capital. Sachs and Malaney (2002) summarise some of the mechanisms by which malaria, for example, affects human capital acquisition, including school absenteeism and impairment of cognitive development.

${ }^{4}$ In contrast, some studies (for example, Cutler et al., 2006) argue that the role of income in improving health is often overstated. Instead, they emphasise the importance of knowledge and technology in enhancing both health and income.

${ }^{5}$ These measures of different dimensions of institutional quality (voice and accountability, political stability and absence of violence, government effectiveness, regulatory quality, rule of law, and control of corruption) are compiled by the World Bank from a wide variety of sources (Kaufmann et al., 2007) are often used as proxies for formal institutions in studies of the deep determinants of development (for example, Easterly and Levine, 2003; Rodrik et al., 2004; Carstensen and Gundlach, 2006). We focus on results for the mean measure. Aggregation is likely to reduce imprecision due to measurement error in the individual components. Also, the different components appear to measure essentially the same underlying concept, so averaging is appropriate (Langbein and Knack, 2008).

${ }^{6}$ Settler mortality, a widely used instrument for formal institutions proposed by Acemoglu et al. (2001), is not included in our instrument set because the useable sample, formed by the intersection of countries for which data are available on settler mortality and the WVS measures of informal institutions, would be substantially reduced. 
${ }^{7}$ Stock and Yogo (2005) derive critical values for different values of the number of included endogenous regressors $(n)$, the number of (excluded) instrumental variables $\left(K_{2}\right)$ and the desired maximal size of a 5 percent Wald test if using 2SLS. Stock and Yogo's tabulated critical values are for $n$ up to 2, but, using the extended set of critical values for 2SLS in Batten and Martina (2007) with $n=3$ and $K_{2}=6$, a value of the Cragg-Donald $F$-statistic, $C D-F=1.97$ implies that the null hypothesis of weak instruments is not rejected in the case in which the maximum 2SLS size is no more than 15 percent, corresponding to a maximum size distortion of 10 percent.

${ }^{8}$ Different variants of the Fuller estimator arise from the choice of the Fuller parameter, $\alpha$. Choosing $\alpha=1$ gives an estimator with a zero higher-order mean bias, whereas $\alpha=4$ leads to non-zero bias but a smaller mean squared error (Fuller, 1977). The estimates reported are for the Fuller estimator with $\alpha=1$, which Fuller recommends for hypothesis testing. However, we also examine the sensitivity of the results to setting $\alpha=4$.

${ }^{9}$ Fuller estimates with Bekker standard errors are computed in TSP, version 5.0; all other estimates and test statistics are obtained using the ivreg2 command (Baum et al., 2007) in Stata, version 10 .

${ }^{10}$ The restriction that the coefficients are equal for the three components can be tested by fitting a more general model with the three components of Inform entered separately, although we maintain a composite Inform measure in the interaction term (to avoid a large number of endogenous regressors). The hypothesis that Trust, Respect and Control have equal coefficients is not rejected using an asymptotic chi-squared test $\left(\chi^{2}(2)=0.289, p=0.866\right.$ for the restricted model reported in Table 2, column (iii)). Similarly, for the variant of Inform that includes only Trust and Control, we enter both components separately and, in this simpler case, also allow for separate interaction terms with Formal. Again, the joint hypothesis that the coefficients on Trust and Control are equal and the coefficients on Trust $\times$ Formal and Control $\times$ Formal are equal is not rejected $\left(\left(\chi^{2}(2)=0.175, p=0.916\right.\right.$ for the restricted model reported in Table 2, column (iii)).

11 The 2SLS estimates in column (i) are similar to the Fuller(1) estimates, with, generally, smaller estimated standard errors, although these do not qualitatively alter the interpretation of statistical significance of the various coefficients. Computing a Wu-Hausman $F$-test statistic of the hypothesis that the three endogenous explanatory variables can be treated as exogenous yields a $p$-value of 0.00001 for the model in column (i), implying that the institutions variables are not exogenous and OLS estimates of the parameters in equation (1) would be inconsistent. 
12 The percentage change in the predicted value of $(85-L E)$ is calculated as $[\exp (b \Delta x)-$ $1] \times 100$, where $b$ is the estimated marginal effect for variable $x$.

${ }^{13}$ Data for the Gini coefficient are from the World Development Indicators (2007). For some countries the data are based on inequality of consumption, and, for others, inequality of income. As argued by Knowles (2005), this may bias the results. However, consistently measured data are not available for a large enough sample. 


\section{References}

Acemoglu, D., Johnson, S. and Robinson, J.A. (2001) The colonial origins of comparative development: an empirical investigation. American Economic Review, 91, pp. 1369-1401.

Acemoglu, D., Johnson, S. and Robinson, J.A. (2002) Reversal of fortune: geography and institutions in the making of the modern world income distribution. Quarterly Journal of Economics, 117, pp. 1231-1294.

Ahlerup, P., Olsson, O. and Yanagizawa, D. (2008) Social capital vs institutions in the growth process. European Journal of Political Economy, in press.

Aiken, L.S. and West, S.G. (1991) Multiple Regression: Testing and Interpreting Interactions (London: Sage).

Alesina, A. and La Ferrara, E. (2002) Who trusts others? Journal of Public Economics, 85, $207-$ 234.

Andrews, D.W.K. and Stock, J.H. (2007) Inference with weak instruments, in: R. Blundell, W.K. Newey and T. Persson (eds) Advances in Economics and Econometrics: Theory and Applications, Ninth World Congress, Volume III (Cambridge: Cambridge University Press), pp. 122-173.

Batten, A. and Martina, A. (2007) Diseases dominate, in: W.R. Garside (ed.) Institutions and Market Economies: The Political Economy of Growth and Development (Basingstoke: Palgrave Macmillan), pp. 186-221.

Baum, C.F., Shaffer, M.E. and Stillman, S. (2007) Enhanced routines for instrumental variables/generalized method of moments estimation and testing. Stata Journal, 7, pp. 465506.

Bekker, P.A. (1994) Alternative approximations to the distributions of instrumental variable estimators. Econometrica, 62, pp. 657-681.

Berggren, N. and Jordahl, H. (2006) Free to trust: economic freedom and social capital. Kyklos, 59, pp. 141-169.

Bjørnskov, C., Dreher, A. and Fischer, J.A.V. (2008) Formal institutions and subjective wellbeing: revisiting the cross-country evidence. KOF Swiss Economic Institute, Working Papers No. 192.

Bloom, D.E. and Canning, D. (2000) The health and wealth of nations. Science, 287, pp. 12071209.

Bloom, D.E. and Sachs, J.D. (1998) Geography, demography, and economic growth in Africa. Brookings Papers on Economic Activity, Issue 2, pp. 207-273.

Bockstette V., Chanda A. and Putterman, L. (2002) States and markets: the advantage of an early start. Journal of Economic Growth, 7, pp. 347-369.

Brambor, T., Clark, W.R. and Golder, M. (2006) Understanding interaction models: improving empirical analyses. Political Analysis, 14, pp. 63-82.

Carstensen, K. and Gundlach, E. (2006) The primacy of institutions reconsidered: direct income effects of malaria prevalence. World Bank Economic Review, 20, pp. 309-339.

Chaudhury, N., Hammer, J., Kremer, M., Muralidharan, K. and Rogers, F.H. (2006) Missing in action: teacher and health worker absence in developing countries. Journal of Economic Perspectives, 20, pp. 91-116.

Commission on Macroeconomics and Health (2001) Macroeconomics and Health: Investing in Health for Economic Development (Geneva: World Health Organization).

Cragg, J.G. and Donald, S.G. (1993) Testing identifiability and specification in instrumental variable models. Econometric Theory, 9, pp. 222-240.

Cutler, D., Deaton, A., and Lleras-Muney, A. (2006) The determinants of mortality. Journal of Economic Perspectives, 20, pp. 97-120. 
Deaton, A. (2003) Health, inequality, and economic development. Journal of Economic Literature, 41, pp. 113-158.

Dixit, A. (2004) Lawlessness and Economics: Alternative Modes of Governance (Oxford: Oxford University Press).

Easterly, W. and Levine, R. (2003) Tropics, germs, and crops: how endowments influence economic development. Journal of Monetary Economics, 50, 3-39.

Fafchamps. M. (2006) Development and social capital. Journal of Development Studies, 42, pp. 1180-1198.

Faye, M.L, McArthur, J.W., Sachs, J.D. and Snow, T. (2004) The challenges facing landlocked developing countries. Journal of Human Development, 5, pp. 31-68.

Fielding, D. and Torres, S. (2008) Cows and conquistadors: a contribution on the colonial origins of comparative development. Journal of Development Studies, 44, pp. 1081-1099.

Filmer, D. and Pritchett, L. (1999) The impact of public spending on health: does money matter? Social Science \& Medicine, 49, pp. 1309-1323.

Flores-Lagunes, A. (2007) Finite sample evidence of IV estimators under weak instruments. Journal of Applied Econometrics, 22, pp. 677-694.

Frankel, J. and Romer, D. (1999) Does trade cause growth? American Economic Review, 89, pp. 379-399.

Frankel, J. and Rose. A. (2002) An estimate of the effect of common currencies on trade and income. Quarterly Journal of Economics, 117, pp. 437-466.

Fuller, W.A. (1977) Some properties of a modification of the limited information estimator. Econometrica, 45, pp. 939-953.

Gallup, J.L., Sachs, J.D. and Mellinger, A.D. (1999) Geography and economic development. International Regional Science Review, 22, pp. 179-232.

Galor, O. and Moav, O. (2007) The Neolithic revolution and contemporary variations in life expectancy. Brown University, Department of Economics, Working Paper 2007-14.

Guernier, V., Hochberg, M.E. and Guégan, J.-F. (2004) Ecology drives the worldwide distribution of human diseases. PLoS Biology, 2, pp. 740-746.

Guiso, L., Sapienza, P. and Zingales, L. (2006) Does culture affect economic outcomes? Journal of Economic Perspectives, 20, pp. 23-48.

Hahn, J., Hausman, J. and Kuersteiner, G. (2004) Estimation with weak instruments: accuracy of higher-order bias and MSE approximations. Econometrics Journal, 7, pp. 272-306.

Hall, R.E. and Jones, C.I. (1999) Why do some countries produce so much more output per worker than others? Quarterly Journal of Economics, 114, pp. 83-116.

Hansen, C., Hausman, J. and Newey, W. (2008) Estimation with many instrumental variables. Journal of Business and Economic Statistics, 26, pp. 398-422.

Hansen, L. (1982) Large sample properties of generalized method of moments estimators. Econometrica, 50, pp. 1029-1054.

Hansen, L., Heaton, J. and Yaron, A. (1996) Finite sample properties of some alternative GMM estimators. Journal of Business and Economic Statistics, 14, pp. 262-280.

Inglehart, R. and Baker, W.E. (2000) Modernization, cultural change, and the persistence of traditional values. American Sociological Review, 65, pp. 19-51.

Inglehart, R., Basáñez, M., Díez-Medrano, J., Halman, L. and Luijkx, R. (2004) Human Beliefs and Values: A Cross-Cultural Sourcebook Based on the 1999-2002 Values Surveys (Mexico City: Siglo XXI Editores).

Islam, M.K., Merlo, J., Kawachi, I., Lindström, M. and Gerdtham, U.-G. (2006) Social capital and health: does egalitarianism matter? A literature review. International Journal for Equity in Health, 5, pp. 1-28.

Jones, H.B. (1997) The Protestant ethic: Weber's model and the empirical literature. Human Relations, 50, pp. 757-778. 
Jones, M., Knowles, S. and Owen, P.D. (2007) The deep determinants of health and education: institutions versus geography, in: W.R. Garside (ed.) Institutions and Market Economies: The Political Economy of Growth and Development (Basingstoke: Palgrave Macmillan), pp. 167-185.

Kaufmann, D., Kraay, A. and Mastruzzi, M. (2007) Governance matters VI: aggregate and individual governance indicators 1996-2006. World Bank Policy Research Working Paper No. 4280.

Kennelly, B., O'Shea, E. and Garvey, E. (2003) Social capital, life expectancy and mortality: a cross-national examination. Social Science \& Medicine, 56, pp. 2367-2377.

Kleibergen, F. and Paap, R. (2006) Generalized reduced rank tests using the singular value decomposition. Journal of Econometrics, 133, pp. 97-126.

Klomp, J. and de Haan, J. (2008) Effects of governance on health: a cross-national analysis of 101 countries. Kyklos, 61, pp. 599-614.

Knack, S. and Keefer, P. (1997) Does social capital have an economic payoff? A cross-country investigation. Quarterly Journal of Economics, 112, pp. 1251-1288.

Knowles, S. (2005) Inequality and economic growth: the empirical relationship reconsidered in the light of comparable data. Journal of Development Studies, 41, pp. 135-159.

Knowles, S. (2007) Is social capital part of the institutions continuum and is it a deep determinant of development?, in: G. Mavrotas and A. Shorrocks (eds) Advancing Development: Core Themes in Global Economics (Basingstoke: Palgrave MacMillan), pp. 197-223.

Knowles, S. and Owen, P.D. (1995) Health capital and cross-country variation in income per capita in the Mankiw-Romer-Weil model. Economics Letters, 48, pp. 99-106.

Knowles, S. and Owen, P.D. (1997) Education and health in an effective-labour empirical growth model. Economic Record, 73, pp. 314-328.

Landes, D. (1998) The Wealth and Poverty of Nations: Why Some Are So Rich and Some So Poor (New York, NY: W.W. Norton).

Langbein, L. and Knack, S. (2008) The Worldwide Governance Indicators and tautology: causally related separable concepts, indicators of a common cause, or both? World Bank Policy Research Working Paper 4669.

La Porta, R., Lopez-de-Silanes, F. and Schleifer, A. (2008) The economic consequences of legal origins. Journal of Economic Literature, 46, pp. 285-332.

La Porta, R., Lopez-De-Silanes, F., Shleifer, A. and Vishny, R.W. (1997) Trust in large organizations. American Economic Review, 87, pp. 333-338.

La Porta, R., Lopez-de-Silanes, F., Schleifer, A. and Vishny, R. (1999) The quality of government. Journal of Law, Economics, and Organization, 15, pp. 222-282.

Lazarova, E.A. and Mosca, I. (2008) Does governance matter for aggregate health capital? Applied Economics Letters, 15, pp. 199-202.

Lynch, J., Davey Smith, G., Hillemeier, M., Shaw, M., Raghunathan, T. and Kaplan, G. (2001) Income inequality, the psychosocial environment, and health: comparisons of wealthy nations. The Lancet, 358, July 21, pp. 194-200.

Masters, W.A. and McMillan, M.S. (2001) Climate and scale in economic growth. Journal of Economic Growth, 6, pp. 167-186.

McArthur, J.W. and Sachs, J.D. (2001) Institutions and geography: comment on Acemoglu, Johnson and Robinson (2000). National Bureau of Economic Research, NBER Working Paper 8114.

North, D. (1990) Institutions, Institutional Change and Economic Performance (Cambridge: Cambridge University Press).

Olsson, O. and Hibbs, D.A., Jr. (2005) Biogeography and long-run economic development. European Economic Review, 49, pp. 909-938. 
Owen, A.L. and Wu, S. (2007) Is trade good for your health? Review of International Economics, 15, pp. 660-682.

Pagan, A.R. and Hall, A.D. (1983) Diagnostic tests as residual analysis. Econometric Reviews, 2, pp. 159-218.

Papageorgiou, C., Savvides, A. and Zachariadis, M. (2007) International medical technology diffusion. Journal of International Economics, 72, pp. 409-427.

Pesaran, M.H. and Taylor, L.W. (1999) Diagnostics for IV regressions. Oxford Bulletin of Economics and Statistics, 61, pp. 255-281.

Platteau, J.-P. (1994a) Behind the market stage where real societies exist - part I: the role of public and private order institutions. Journal of Development Studies, 30, pp. 533-577.

Platteau, J.-P. (1994b) Behind the market stage where real societies exist - part II: the role of moral norms. Journal of Development Studies, 30, pp. 753-817.

Pritchett, L. and Summers, L.H. (1996) Wealthier is healthier. Journal of Human Resources, 31, pp. 841-868.

Putnam, R.D., Leonardi, R. and Nanetti. R.Y. (1993) Making Democracy Work: Civic Traditions in Modern Italy (Princeton: Princeton University Press).

Rodrik, D., Subramanian, A. and Trebbi, F. (2004) Institutions rule: the primacy of institutions over geography and integration in economic development. Journal of Economic Growth, 9, pp. 131-165.

Sachs, J. (2001) Tropical underdevelopment. National Bureau of Economic Research, NBER Working Paper 8119.

Sachs, J. (2003) Institutions don't rule: direct effects of geography on per capita income. National Bureau of Economic Research, NBER Working Paper 9490.

Sachs, J. and Malaney, P. (2002) The economic and social burden of malaria. Nature, 415, pp. 680-685.

Sachs, J.D. and Warner, A.M. (1995) Economic reform and the process of global integration. Brookings Papers on Economic Activity, Issue 1, pp. 1-95.

Sargan, J.D. (1958) The estimation of economic relationships with instrumental variables. Econometrica, 26, pp. 393-415.

Shea, J. (1997) Instrument relevance in multivariate linear models: a simple measure. Review of Economics and Statistics, 79, pp. 348-352.

Stock, J.H. and Yogo, M. (2005) Testing for weak instruments in linear IV regression, in: D.W.K. Andrews and J.H. Stock (eds) Identification and Inference for Econometric Models: Essays in Honor of Thomas Rothenberg (Cambridge: Cambridge University Press), pp. 80-108.

Tabellini, G. (2007) Culture and institutions: economic development in the regions of Europe. Mimeo, IGIER, Bocconi University (revised version of CESIFO Working Paper No. 1492).

Voigt, S. and Park, S.-M. (2008) Values and norms matter - on the basic determinants of longrun economic development. Joint Discussion Paper Series in Economics by the Universities of Aachen, Gießen, Göttingen, Kassel, Marburg and Siegen, No. 22-2008.

Wacziarg, R. and Welch, K.H. (2008) Trade liberalization and growth: new evidence. World Bank Economic Review, 22, pp. 187-231.

Weber, M. (1958) The Protestant Ethic and the Spirit of Capitalism (translated by Talcott Parsons) (New York: Charles Scribner's Sons) (originally published 1904-5).

Woolcock, M. and Radin, E. (2008) A relational approach to the theory and practices of economic development, in: D. Castiglione, J.W. van Deth and G. Wolleb (eds) The Handbook of Social Capital (Oxford: Oxford University Press), pp. 411-437.

World Bank (2007) World Development Indicators 2007 (Washington, DC: The World Bank). Zak, P.J. and Knack, S. (2001) Trust and growth. Economic Journal, 111, pp. 295-321. 
Table 1. Summary Statistics

\begin{tabular}{lccccc}
\hline Variable & $N$ & Mean & $\begin{array}{c}\text { Standard } \\
\text { Deviation }\end{array}$ & Min & Max \\
\hline LE & 73 & 73 & 7.88 & 42 & 82 \\
Formal & 73 & 56.99 & 19.24 & 16.56 & 88.98 \\
Informal & 73 & 52.04 & 9.99 & 31.67 & 77.67 \\
Trust & 73 & 28.49 & 15.27 & 3 & 67 \\
Control & 73 & 57.58 & 14.98 & 11 & 82 \\
Respect & 73 & 70.05 & 10.17 & 48 & 93 \\
\hline
\end{tabular}

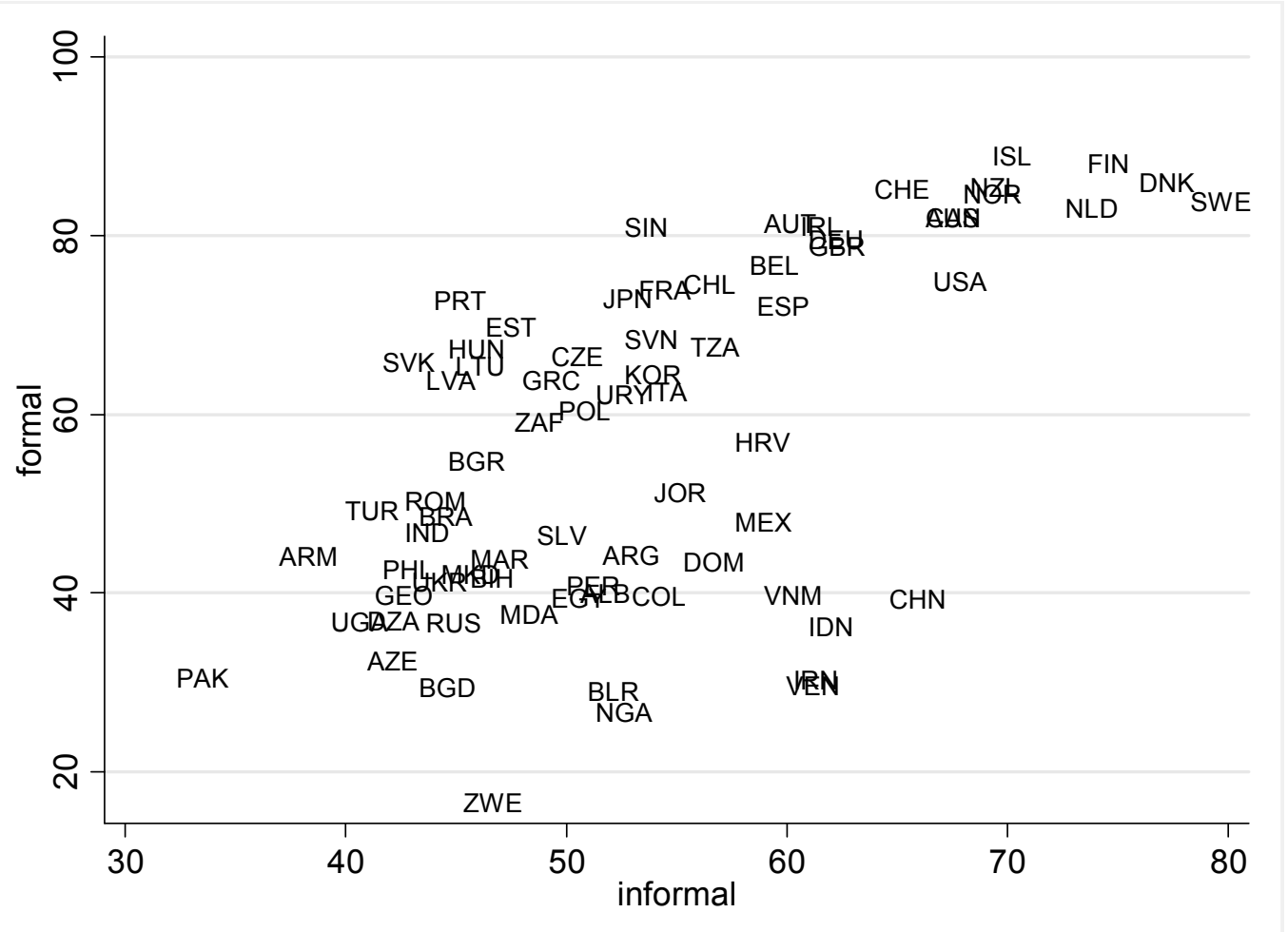

Figure 1. Cross-plot of Formal and Informal 
Table 2. Deep Determinants of Life Expectancy: 2SLS and Modified LIML Results

\begin{tabular}{|c|c|c|c|c|}
\hline Estimation method & $\begin{array}{l}\text { (i) } \\
\text { 2SLS }\end{array}$ & $\begin{array}{c}\text { (ii) } \\
\text { Fuller(1) }\end{array}$ & $\begin{array}{c}\text { (iii) } \\
\text { Fuller(1) }\end{array}$ & $\begin{array}{c}\text { (iv) } \\
\text { Fuller(1) }\end{array}$ \\
\hline Constant & $\begin{array}{l}-8.135^{* * *} \\
(4.79)\end{array}$ & $\begin{array}{l}-7.859 * * * \\
(4.70)\end{array}$ & $\begin{array}{l}-8.117 * * * \\
(4.70)\end{array}$ & $\begin{array}{l}-6.113^{* * *} \\
(5.81)\end{array}$ \\
\hline Formal & $\begin{array}{l}0.073^{* * *} \\
(2.91)\end{array}$ & $\begin{array}{l}0.071^{* * *} \\
(2.83)\end{array}$ & $\begin{array}{l}0.074 * * * \\
(2.88)\end{array}$ & $\begin{array}{l}0.055^{* * *} \\
(3.21)\end{array}$ \\
\hline Informal $(T+C+R)$ & $\begin{array}{l}0.113^{* * *} \\
(3.16)\end{array}$ & $\begin{array}{l}0.106^{* * *} \\
(3.03)\end{array}$ & $\begin{array}{l}0.113^{* * *} \\
(3.10)\end{array}$ & \\
\hline Informal $(T+C)$ & & & & $\begin{array}{l}0.080 * * * \\
(3.23)\end{array}$ \\
\hline Formal $\times$ Informal & $\begin{array}{l}-0.001 * * * \\
(2.81)\end{array}$ & $\begin{array}{l}-0.001 * * * \\
(2.68)\end{array}$ & $\begin{array}{l}-0.001 * * * \\
(2.75)\end{array}$ & $\begin{array}{l}-0.001 * * * \\
(2.84)\end{array}$ \\
\hline TropicArea & $\begin{array}{l}-0.572 * * * \\
(2.88)\end{array}$ & $\begin{array}{l}-0.549 * * * \\
(2.78)\end{array}$ & $\begin{array}{l}-0.544 * * * \\
(2.65)\end{array}$ & $\begin{array}{l}-0.430^{* *} \\
(2.39)\end{array}$ \\
\hline Land $100 \mathrm{~km}$ & $\begin{array}{c}0.176 \\
(1.09)\end{array}$ & $\begin{array}{c}0.174 \\
(1.06)\end{array}$ & & \\
\hline Africa & $\begin{array}{l}-0.427^{* *} \\
(2.25)\end{array}$ & $\begin{array}{l}-0.435^{* *} \\
(2.27)\end{array}$ & $\begin{array}{c}-0.477^{* *} \\
(2.37)\end{array}$ & $\begin{array}{c}-0.439 * * \\
(2.25)\end{array}$ \\
\hline Communist & $\begin{array}{l}-0.269^{* *} \\
(2.07)\end{array}$ & $\begin{array}{l}-0.268^{* *} \\
(2.02)\end{array}$ & $\begin{array}{l}-0.295^{* *} \\
(2.14)\end{array}$ & $\begin{array}{c}-0.225^{*} \\
(1.69)\end{array}$ \\
\hline$N$ & 73 & 73 & 73 & 73 \\
\hline$R^{2}$ & 0.614 & 0.634 & 0.603 & 0.637 \\
\hline PH-Hetero- $p$ & 0.971 & 0.953 & 0.929 & 0.922 \\
\hline$R E S E T-p$ & 0.262 & 0.264 & 0.417 & 0.248 \\
\hline$S A R G A N-p$ & 0.989 & 0.982 & 0.979 & 0.944 \\
\hline$C D-F$ & 1.974 & 1.974 & 1.689 & 3.006 \\
\hline$\mu^{2}$ & 11.843 & 11.843 & 10.133 & 18.037 \\
\hline
\end{tabular}

Notes: Fuller(1) estimates obtained with Fuller constant $\alpha=1$. For Fuller estimates, asymptotic $t$-values based on Bekker standard errors are reported in parentheses. Additional instruments: StateHist, EngFrac, EngLegor, ProtFrac, CathFrac and MuslimFrac. $R^{2}$ is calculated as the squared correlation between the observed and predicted values of the dependent variable. PH-Hetero- $p$ is the $p$-value for Pagan and Hall's (1983) heteroskedasticity test (using levels and squares of IVs), RESET- $p$ is the $p$-value for Pesaran and Taylor's (1999) variant of the RESET test, SARGAN-p is the $p$-value for Sargan's (1958) test of overidentifying restrictions. $C D-F$ and $\mu^{2}$ are, respectively, the $F$-statistic form of Cragg and Donald's (1993) test for weak instruments and the estimated concentration parameter. T, $C$ and $R$ represent the Trust, Control and Respect components of the Informal measure. *, ** and *** denote statistical significance at the 10,5 and 1 per cent levels respectively. 
Table 3. Deep Determinants of Life Expectancy: Robustness I

\begin{tabular}{|c|c|c|c|c|}
\hline Estimation method & $\begin{array}{c}\text { (i) } \\
\text { Fuller(4) }\end{array}$ & $\begin{array}{l}\text { (ii) } \\
\text { GMM }\end{array}$ & $\begin{array}{c}\text { (iii) } \\
\text { GMM (robust) }\end{array}$ & $\begin{array}{l}\text { (iv) } \\
\text { CUE }\end{array}$ \\
\hline Constant & $\begin{array}{l}-7.353^{* * *} \\
(5.28)\end{array}$ & $\begin{array}{l}-8.408 * * * \\
(4.74)\end{array}$ & $\begin{array}{l}-8.427 * * * \\
(4.04)\end{array}$ & $\begin{array}{l}-8.494 * * * \\
(4.00)\end{array}$ \\
\hline Formal & $\begin{array}{l}0.066^{* * *} \\
(3.17)\end{array}$ & $\begin{array}{l}0.076^{* * * *} \\
(2.92)\end{array}$ & $\begin{array}{l}0.076^{* * * *} \\
(2.88)\end{array}$ & $\begin{array}{l}0.076^{* * * *} \\
(2.82)\end{array}$ \\
\hline $\begin{array}{l}\text { Informal } \\
(T+C+R)\end{array}$ & $\begin{array}{l}0.095^{* * * *} \\
(3.27)\end{array}$ & $\begin{array}{l}0.121^{* * *} \\
(3.18)\end{array}$ & $\begin{array}{l}0.122 * * * \\
(2.60)\end{array}$ & $\begin{array}{l}0.124 * * * \\
(2.60)\end{array}$ \\
\hline Formal $\times$ Informal & $\begin{array}{l}-0.001 * * * \\
(2.86)\end{array}$ & $\begin{array}{l}-0.001 * * * \\
(2.83)\end{array}$ & $\begin{array}{l}-0.001 * * * \\
(2.65)\end{array}$ & $\begin{array}{l}-0.001 * * * \\
(2.64)\end{array}$ \\
\hline TropicArea & $\begin{array}{l}-0.474 * * * \\
(2.79)\end{array}$ & $\begin{array}{l}-0.573 * * * \\
(2.72)\end{array}$ & $\begin{array}{l}-0.597 * * \\
(2.18)\end{array}$ & $\begin{array}{l}-0.609 * * \\
(2.14)\end{array}$ \\
\hline Africa & $\begin{array}{l}-0.495^{* *} \\
(2.79)\end{array}$ & $\begin{array}{l}-0.471 * * \\
(2.33)\end{array}$ & $\begin{array}{l}-0.491^{*} \\
(1.85)\end{array}$ & $\begin{array}{l}-0.492^{*} \\
(1.81)\end{array}$ \\
\hline Communist & $\begin{array}{l}-0.288^{* *} \\
(2.36)\end{array}$ & $\begin{array}{l}-0.298 * * \\
(2.17)\end{array}$ & $\begin{array}{l}-0.306^{* *} \\
(1.97)\end{array}$ & $\begin{array}{c}-0.308^{*} \\
(1.92)\end{array}$ \\
\hline$N$ & 73 & 73 & 73 & 73 \\
\hline$R^{2}$ & 0.664 & 0.516 & 0.499 & 0.486 \\
\hline PH-Hetero- $p$ & 0.765 & 0.958 & 0.968 & 0.973 \\
\hline$R E S E T-p$ & 0.455 & 0.410 & 0.609 & 0.626 \\
\hline$S A R G A N-p$ & 0.823 & 0.987 & & \\
\hline$H A N S E N-J-p$ & & & 0.976 & 0.978 \\
\hline$C D-F$ & 1.689 & 1.689 & & \\
\hline$K P-F$ & & & 1.612 & 1.612 \\
\hline
\end{tabular}


Table 4. Deep Determinants of Life Expectancy: Robustness II

\begin{tabular}{|c|c|c|c|c|c|c|}
\hline & (i) & (ii) & (iii) & (iv) & (v) & (vi) \\
\hline Constant & $\begin{array}{l}-7.619 * * * \\
(4.77)\end{array}$ & $\begin{array}{l}-8.911 * * * \\
(3.79)\end{array}$ & $\begin{array}{l}-7.647 * * * \\
(4.64)\end{array}$ & $\begin{array}{l}-9.472 * * * \\
(4.11)\end{array}$ & $\begin{array}{l}-8.344 * * * \\
(4.71)\end{array}$ & $\begin{array}{l}-8.727 * * * \\
(4.56)\end{array}$ \\
\hline $\begin{array}{l}\text { Formal } \\
\text { (Composite) }\end{array}$ & $\begin{array}{l}0.088^{* * * *} \\
(2.94)\end{array}$ & $\begin{array}{l}0.095 * * * \\
(2.65)\end{array}$ & $\begin{array}{l}0.068^{* * * *} \\
(2.77)\end{array}$ & $\begin{array}{l}0.083^{* * * *} \\
(2.63)\end{array}$ & & \\
\hline $\begin{array}{l}\text { Formal } \\
\text { (Rule) }\end{array}$ & & & & & $\begin{array}{l}0.076^{* * * *} \\
(2.80)\end{array}$ & \\
\hline $\begin{array}{l}\text { Formal } \\
\text { (GovEffec) }\end{array}$ & & & & & & $\begin{array}{l}0.077 * * * \\
(2.78)\end{array}$ \\
\hline $\begin{array}{l}\text { Informal } \\
(T+C+R)\end{array}$ & $\begin{array}{l}0.120^{* * *} \\
(3.31)\end{array}$ & $\begin{array}{l}0.115^{* * *} \\
(2.59)\end{array}$ & $\begin{array}{l}0.103^{* * *} \\
(2.90)\end{array}$ & $\begin{array}{l}0.134^{* * *} \\
(2.74)\end{array}$ & $\begin{array}{l}0.116^{* * *} \\
(3.14)\end{array}$ & $\begin{array}{l}0.125^{* * *} \\
(3.19)\end{array}$ \\
\hline $\begin{array}{l}\text { Formal } \times \\
\text { Informal }\end{array}$ & $\begin{array}{l}-0.002 * * * \\
(3.00)\end{array}$ & $\begin{array}{l}-0.002 * * * \\
(2.59)\end{array}$ & $\begin{array}{l}-0.001 * * \\
(2.56)\end{array}$ & $\begin{array}{l}-0.002 * * * \\
(2.58)\end{array}$ & $\begin{array}{l}-0.001 * * * \\
(2.79)\end{array}$ & $\begin{array}{l}-0.001 * * * \\
(2.77)\end{array}$ \\
\hline TropicArea & $\begin{array}{l}-0.445^{* *} \\
(1.97)\end{array}$ & $\begin{array}{l}-0.304 * \\
(1.64)\end{array}$ & $\begin{array}{c}-0.441 \\
(1.44)\end{array}$ & & $\begin{array}{l}-0.498 * * \\
(2.00)\end{array}$ & $\begin{array}{l}-0.544 * * * \\
(2.65)\end{array}$ \\
\hline Africa & $\begin{array}{l}-0.523 * * * \\
(2.81)\end{array}$ & $\begin{array}{c}-0.292 \\
(1.32)\end{array}$ & $\begin{array}{l}-0.436^{*} \\
(1.91)\end{array}$ & $\begin{array}{l}-0.512^{* *} \\
(2.13)\end{array}$ & $\begin{array}{l}-0.452^{* *} \\
(2.17)\end{array}$ & $\begin{array}{l}-0.472 * * \\
(2.28)\end{array}$ \\
\hline Communist & $\begin{array}{l}-0.500 * * * \\
(3.22)\end{array}$ & $\begin{array}{l}-0.253 \\
(0.93)\end{array}$ & $\begin{array}{l}-0.279^{* *} \\
(2.03)\end{array}$ & $\begin{array}{l}-0.533^{* *} \\
(2.27)\end{array}$ & $\begin{array}{r}-0.217 \\
(1.42)\end{array}$ & $\begin{array}{c}-0.254^{*} \\
(1.79)^{*}\end{array}$ \\
\hline Gini & $\begin{array}{l}-0.019^{* *} \\
(2.44)\end{array}$ & & & & & \\
\hline Openness & & $\begin{array}{r}0.169 \\
(0.38)\end{array}$ & & & & \\
\hline Malfal & & & $\begin{array}{l}-0.255 \\
(0.44)\end{array}$ & & & \\
\hline AvLat & & & & $\begin{array}{l}0.021^{* *} \\
(2.14)\end{array}$ & & \\
\hline$N$ & 65 & 55 & 71 & 73 & 73 & 73 \\
\hline$R^{2}$ & 0.654 & 0.675 & 0.627 & 0.482 & 0.605 & 0.593 \\
\hline PH-Hetero-p & 0.888 & 0.907 & 0.940 & 0.990 & 0.946 & 0.911 \\
\hline RESET- $p$ & 0.530 & 0.239 & 0.116 & 0.355 & 0.415 & 0.417 \\
\hline$S A R G A N-p$ & 0.518 & 0.869 & 0.969 & 0.827 & 0.947 & 0.973 \\
\hline$C D-F$ & 1.577 & 1.385 & 1.241 & 1.073 & 1.221 & 1.660 \\
\hline$\mu^{2}$ & 9.461 & 9.698 & 8.684 & 6.436 & 7.325 & 9.960 \\
\hline
\end{tabular}




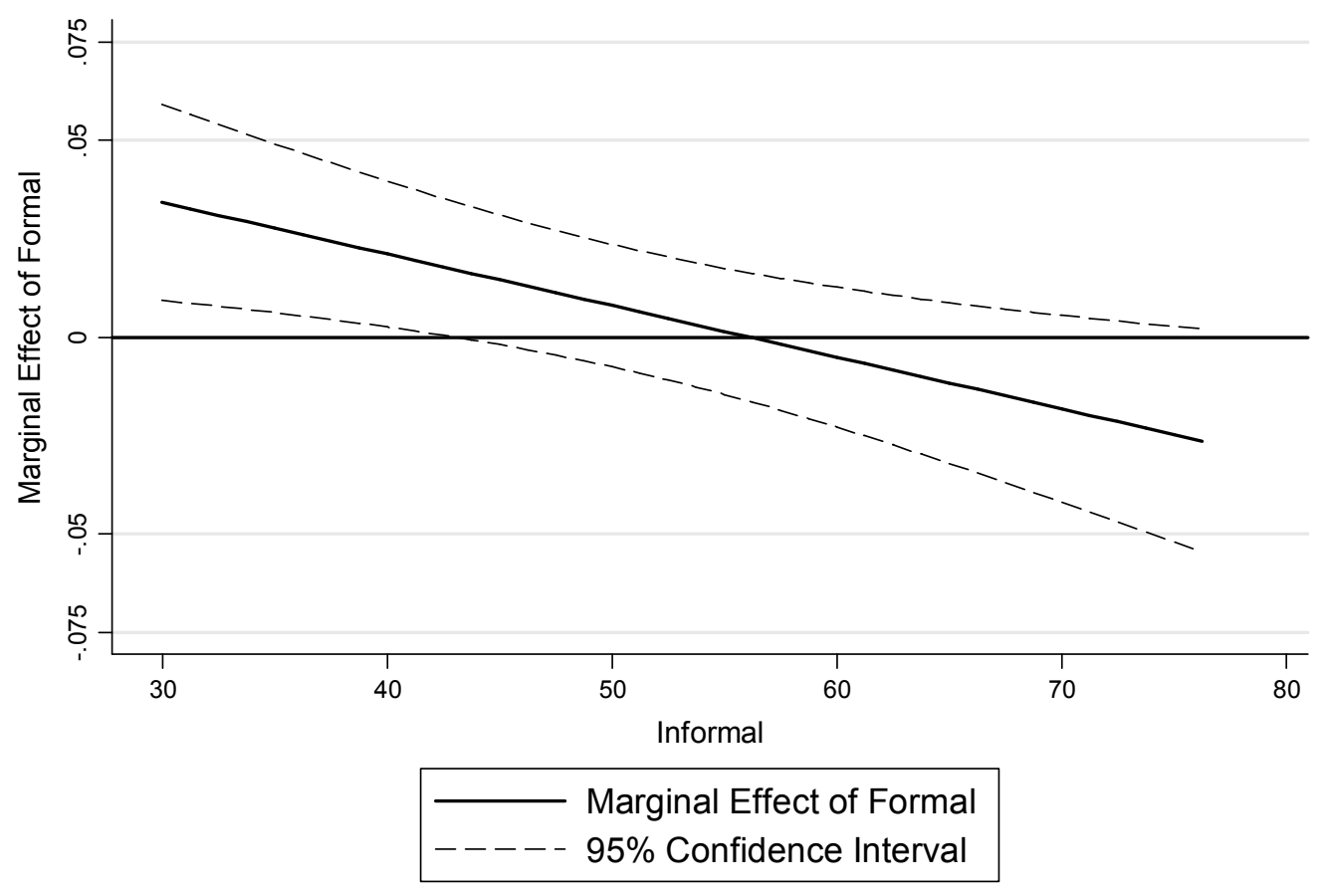

Figure 2. Marginal effect of Formal on $-\ln (85-L E)$ as Informal changes

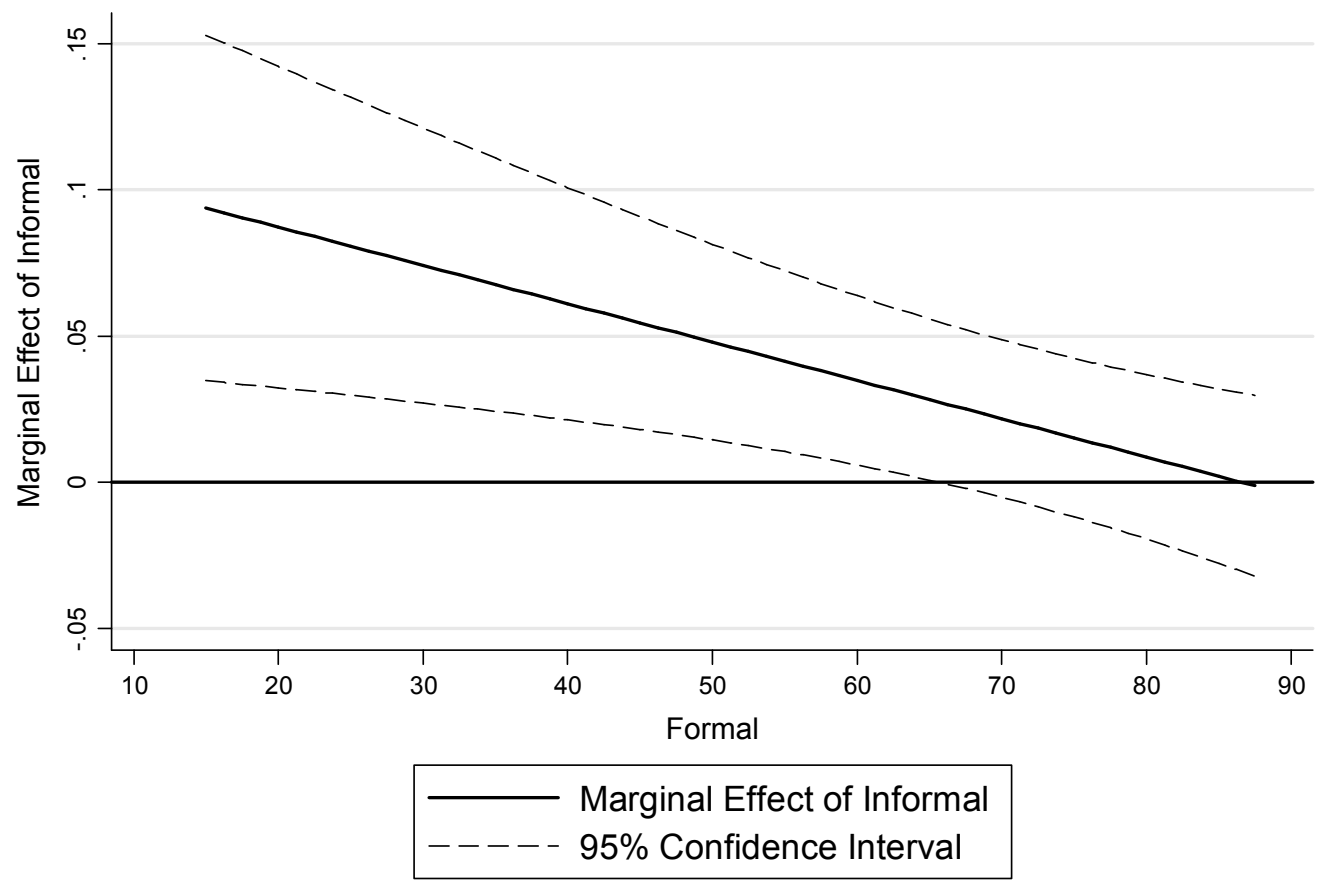

Figure 3. Marginal effect of Informal on $-\ln (85-L E)$ as Formal changes 


\section{Appendix 1: Countries in the sample}

Albania, Algeria, Argentina, Armenia, Australia, Austria, Azerbaijan, Bangladesh, Belarus, Belgium, Bosnia and Herzegovina, Brazil, Bulgaria, Canada, Chile, China, Colombia, Croatia, Czech Republic, Denmark, Dominican Republic, Egypt, El Salvador, Estonia, Finland, France, Georgia, Germany, Greece, Hungary, Iceland, India, Indonesia, Iran, Ireland, Italy, Japan, Jordan, Korea (South), Latvia, Lithuania, Macedonia, Mexico, Moldova, Morocco, Netherlands, New Zealand, Nigeria, Norway, Pakistan, Peru, Philippines, Poland, Portugal, Romania, Russian Federation, Singapore, Slovakia, Slovenia, South Africa, Spain, Sweden, Switzerland, Taiwan, Turkey, Uganda, Ukraine, United Kingdom, United States, Uruguay, Venezuela, Vietnam, Zimbabwe

\section{Appendix 2: Data sources}

Africa: Dummy variable $=1$ if country is in Africa, 0 otherwise.

AvLat: Average (absolute) latitude (degrees). Source: Masters and McMillan (2001).

Communist: Dummy variable $=1$ if country has a communist legacy, 0 otherwise; equivalent to the socialist legal origin dummy defined by La Porta et al. (1999).

Control: measures the percentage of individuals who thought they had 'a great deal' of free choice and control over their lives (scores of 7-10 on a 10-point Likert item), in response to the statement 'Some people feel they have completely free choice and control over their lives, while other people feel that what they do has no real effect on what happens to them' (Inglehart et al., 2004: 419); data are for 2000. Source: Inglehart et al. (2004).

EngFrac: Fraction of population speaking English. Source: Hall and Jones (1999).

EngLegor: Dummy variable $=1$ if country has English legal origin, 0 otherwise. Source: La Porta et al. (1999).

EurFrac: Fraction of the population speaking a major Western European language: English, French, German, Portuguese, or Spanish. Source: Hall and Jones (1999).

Formal: Arithmetic mean of six Worldwide Governance Indicators: voice and accountability, political stability and absence of violence, government effectiveness, regulatory quality, rule of law, and control of corruption; value of index in 2005 converted to a 0-100 scale. Source: Kaufmann et al. (2007). 
FRTrade: Predicted trade shares instrument constructed by Frankel and Rose (2002), updating and extending Frankel and Romer (1999), using a gravity model based on population, area and dummy variables for common language, common border and landlocked status. Source: Frankel and Rose (2002).

Gini: Gini coefficient for within-country income inequality. Source: World Bank (2007).

GovEffec: Index of government effectiveness 'measuring the quality of public services, the quality of the civil service and the degree of its independence from political pressures, the quality of policy formulation and implementation, and the credibility of the government's commitment to such policies'; value of index in 2005 converted to a 0-100 scale. Source: Kaufmann et al. (2007).

Informal: Arithmetic mean of Trust, Respect and Control.

Land100km: Proportion of land area within $100 \mathrm{~km}$ of the seacoast. Source: McArthur and Sachs (2001, Appendix).

$L E$ : life expectancy at birth, total (years) in 2005. Source: World Bank (2007).

Malfal: Proportion of a country's population at risk of falciparum malaria transmission in 1994. Source: Sachs (2003).

$M E$ : Index of malarial ecology based on temperature, mosquito abundance and vector specificity. Source: Sachs (2003).

Openness: Sachs-Warner (1995) index of the fraction of years a nation is 'open' during the period 1965-1990. (Source: Gallup et al., 1999).

ProtFrac, CathFrac and MuslimFrac: proportions of the population that are, respectively, Protestant, Catholic and Muslim. Source: La Porta et al. (1999).

Respect: measures the percentage of individuals who chose 'Tolerance and respect for other people' in response to the question: 'Here is a list of qualities that children can be encouraged to learn at home. Which, if any, do you consider to be especially important? Please choose up to five [out of 10]' (Inglehart et al., 2004: 414); data are for 2000. Source: Inglehart et al. (2004).

Rule: Index of the rule of law 'measuring the extent to which agents have confidence in and abide by the rules of society, and in particular the quality of contract enforcement, the police, 
and the courts, as well as the likelihood of crime and violence'; value of index in 2005 converted to a 0-100 scale. Source: Kaufmann et al. (2007).

StateHist: This index rates the territory defined by the current geographical boundaries of a country in terms of (a) whether the government is above tribal level, (b) whether the government is foreign or locally based, and (c) the percentage territorial coverage of the government, for 50 year sub-periods from 1 to $1950 \mathrm{CE}$. A single observation for each country is obtained by discounting the effect of past values, using a discount rate of 5 per cent. These observations are normalised by dividing by the maximum possible value the series can take for that discount rate. Source: Bockstette et al. (2003) with additional data from http://www.econ.brown.edu/fac/Louis_Putterman/.

TropicArea: Proportion of land area within the tropics. Source: Gallup et al. (1999).

Trust: measures the percentage of individuals who answered 'Most people can be trusted' to the question: 'Generally speaking, would you say that most people can be trusted or that you need to be very careful in dealing with people?' (Inglehart et al., 2004: 415); data are for 2000. Source: Inglehart et al. (2004). 